\title{
Why Human TNF is Not Tumour Necrosis Factor
}

\author{
Abraham Karpas* \\ Emeritus Assistant Director of Research, Department of Haematology, Cambridge University Clinical School, United Kingdom \\ *Corresponding author: Abraham Karpas, Emeritus Assistant Director of Research, Department of Haematology, \\ Cambridge University Clinical School, United Kingdom
}

\author{
ARTICLE INFO \\ Received: 幽 October 30, 2020 \\ Published: 陆 November 16, 2020 \\ Citation: Abraham Karpas. Why Human \\ TNF is Not Tumour Necrosis Factor. \\ Biomed J Sci \& Tech Res 31(5)-2020. \\ BJSTR. MS.ID.005177.
}

ABSTRACT

Abbreviations: BCG: Bacillus Calmette-Guerin; TNF: Tumour Necrosis Factor; RA: Rheumatoid Arthritis

\section{Opinion}

The term TNF originated in a September 1975 article in the Proceedings of the National Academy of Science by Carswell, et al. entitled An Endotoxin-Induced Serum Factor that causes necrosis of tumours [1]. The authors reported that the serum of bacillus Calmette-Guerin (BCG)-infected mice treated with endotoxin contains a substance which they named tumour necrosis factor (TNF) because it mimicked the tumour necrotic action of endotoxin itself on a range of mouse tumours. They found that in vitro it was toxic to two murine neoplastic cell lines but not to mouse embryo cultures. Rats and rabbits, as well as mice, produced TNF. Treatment with both BCG and endotoxin was necessary. TNF was characterized as a glycoprotein with molecular weight 150,000 [1]. Early in 1984 the biotechnology firm Genentech reported in the Journal of Biological Chemistry that they had purified a lymphotoxin with an approximate molecular weight of 20,000 to homogeneity from culture fluid of human lymphoblasts (RPMI-1788 cells) that was likely to be an effective anti-tumour agent [2]. On the basis of this paper the company issued a press release claiming to have unlocked an entirely new anti-cancer agent.

However, by the time they published two major articles in Nature at the end of $1984[3,4]$ about the cloning, expression of the cDNA and structure of their lymphoblastoid-derived lymphotoxin, they revised the molecular mass to 60,000-70,000 (not 20,000), again claiming anti-tumour activity, and also naming it TNF. I then realized that it could be similar to a discovery of mine ten years earlier which described a B-cell cytotoxic lymphokine and therefore claimed priority for it, published in Nature in 1985 [5]. At that time I had been trying to develop leukaemia cell lines from the white blood cells of leukaemia/lymphoma patients, using the culture fluid as well as the newly established haemic cells to try to infect adherent human cells derived from normal embryo lung and skin fibroblasts, together with a range of malignant human and animal cells, in the hope that if any of the leukaemia patients carried an endogenous virus this might replicate and be amplified in some of the target cells. The majority of the haemic cell lines that developed turned out to be EBV-infected lymphoblasts [6] which did not express any other virus and, when added to a range of target cells, did not affect the growth pattern of any of the adherent cells.

Likewise, the culture fluid from the newly established haemic cell lines did not appear to alter the growth pattern of any of the target cells. However, one lymphoblastoid cell line, Karpas-160, proved to be highly cytotoxic to every target cell tested, normal or malignant. This had been derived from a 32-year old patient presenting with a mediastinal mass and lymphadenopathy who was diagnosed as having non-Hodgkin's lymphoma. In the beginning most of the cultured leukaemia cells consisted of small T-cells, but these were overgrown by larger B-cells, eventually giving rise to a population of pleomorphic cells. Ultrastructure examination of the 
latter revealed a very well-developed rough endoplasmic reticulum and Golgi apparatus somewhat resembling plasma cells [7]. Tests for EBNA were positive which meant that they were latently infected with EBV. Some twenty other EBV-infected lymphoblastoid cell lines did not appear to affect the growth of target cells, but the 160-line cells were very cytotoxic to every target cell tested, whether normal or malignant, even when seeded at a ratio of 1:1. Furthermore even small quantities of the culture fluid were cytotoxic.

I was able to determine that this was not due to a virus, but a humoral cytotoxic factor released by the cells. The factor was readily precipitated by $60 \%$ saturation of ammonium sulphate; and therefore, should have been a protein. On centrifugation on a sucrose density gradient it banded at a similar density to haemoglobin; therefore, I assumed it to have an approximate molecular weight of 70,000 [5]. Since it killed normal cells as well I did not think of it as a specific anti-tumour agent but assumed it to be a new human cytotoxic lymphokine, produced by this particular 160 -line in very large quantities. I thought it might turn out to be important, so I wrote up the results and submitted manuscripts to several of the first ranked journals in 1975 but was turned down by sceptical reviewers, one referee even suggesting that I might have fabricated the experimental data. Eventually the British Journal of Cancer accepted my first manuscript in 1976 and it appeared in February 1977 [7], while the second paper was also published in the same journal [8]. Seeing that it was cytotoxic to both malignant and normal human cell lines I never described it as a tumour necrosis factor; and its molecular weight was about 70,000 in contrast to the $150,000 \mathrm{MW}$ of the mouse TNF endotoxin.

However, on further purification and physicochemical Characterisation we determined that it had an apparent molecular weight of 65,000 [9]; subsequently we were able to determine that the cytotoxin produced by the 160 -line contained what Genentech called TNF alpha and beta [10]; and the amino acid sequence of one of our preparations showed homology to TNF beta [11]. Regrettably my applications to grant-giving bodies to follow up further the potential role of these cytotoxic lymphokines in man were turned down repeatedly. Genentech's claim in the press in 1984 to have discovered a new therapy for human cancer with their 20,000 MW substance highlighted the term TNF, a name that was originally given in 1975 to a murine endotoxin with a molecular weight of 150,000. When used as an anti-cancer agent it did not show any clinical benefit despite extensive trials. But the name TNF stuck. Eventually it became an important therapeutic target when the experimental studies of Feldmann's research group discovered that anti-TNF antibodies in a mouse model of rheumatoid arthritis (RA) ameliorated disease activity [12], leading on to the use of monoclonal antibodies against human TNF to treat patients with RA. This proved to be a clinical breakthrough and, incidentally, a financial gold mine for the companies marketing the antibodies [13].

\section{Conclusion}

The term Tumour Necrosis Factor (TNF) was invented in 1975 in New York for a glycoprotein of 150,000 MW that developed in vivo in mice following injection with BCG. What is now named as human TNF was first discovered in 1975 in Cambridge as a protein of about 70,000 MW produced in vitro by a human lymphoblastoid cell line. Some twenty years later this protein has become a most important therapeutic target in rheumatoid arthritis.

\section{References}

1. Carswell EA, Old LJ, Kassel RL, Green S, Fiore N, et al. (1975) An endotoxin-induced serum factor that causes necrosis of tumors. Proc Nat Acad Sci USA 72(9): 3666-3670.

2. Aggarwal BB, Mofat B, Harkins RN (1984) Human lymphotoxin, production by a lymphoblastoid cell line, purification, and initial characterization. J Biological Chemistry 259(1): 686-691.

3. Gray PW, Aggarwal BB, Benton CV, Bringman TS, Henzel WJ, et al. (1984) Cloning and expression of a cDNA for human lymphotoxin, a lymphokine with tumor necrosis activity. Nature 312(5996): 721-724.

4. Pannica D, Nedwin GE, Hayflick JS, Seeburg PH, Derynck R, et al. (1984) Human tumor necrosis factor: precursor structure, expression and homology to lymphotoxin. Nature 312(5996): 724-727.

5. Karpas A (1985) Human B-cell cytotoxic lymphokine priority. Nature 313(6004): 636.

6. Karpas A, Hayhoe FGJ, Greenberger JS, Barker CR, Cawley JC, et al. (1977) The establishment and cytological, cytochemical and immunological characterisation of human haemic cell lines: evidence for heterogeneity. Leukemia Research 1(1): 35-49.

7. Karpas A (1977) A human haemic cell line capable of cellular and humoral killing of normal and malignant cells. Brit J Cancer 35(2): 152160 .

8. Karpas A (1977) A humoral cytotoxic substance produced by human killer cell line. Brit J Cancer 36(4): 437-445.

9. Neumann H, Karpas A (1981) Purification and physiochemical characterisation of a human cytotoxic factor produced by human haemic cell line. Biochem J 194(3): 847-856.

10. Ni J, Meager A, Karpas A (1992) Characterisation and partial purification of a novel cytotoxic lymphokine (Factor 2) produced by a B-cell line (Karpas 160). Inter Immunol 4(4): 519-531.

11. Yamanaka HI, Karpas A (1989) Identity of human B-cell line cytotoxic lymphokine with tumor necrosis factor type beta. Proc Nat Acad Sci USA 86(4): 1343-1347.

12. Williams RO, Feldmann M, Maini RN (1992) Anti-tumor necrosis factor ameliorates joint disease in murine collagen-induced arthritis. Proc Nat Acad Sci USA 89(2): 9784-9788.

13. Feldmann M, Maini RN (2001) Anti-TNF therapy of rheumatoid arthritis: what have we learned? Ann Rev Immunol 19: 163-196. 
ISSN: 2574-1241

DOI: 10.26717/BJSTR.2020.31.005177

Abraham Karpas. Biomed J Sci \& Tech Res

(C) (P) This work is licensed under Creative

Submission Link: https://biomedres.us/submit-manuscript.php

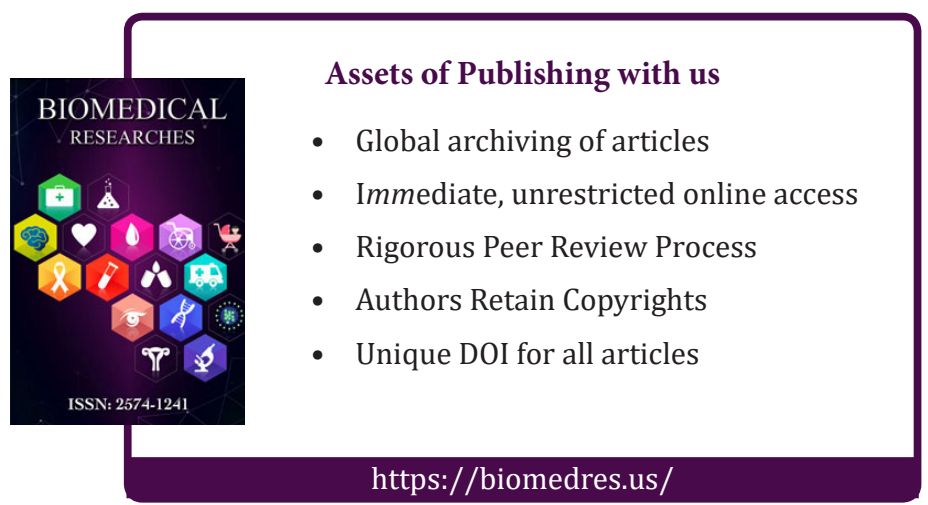

